\title{
Effect of Information Systems on Revenue Collection by Local Authorities in Homa Bay County, Kenya
}

\author{
Odoyo Collins Otieno ${ }^{1}$, Moses Oginda ${ }^{1}$, John Mark Obura ${ }^{1}$, Fredrick O. Aila ${ }^{2, *}$, Patrick B. Ojera ${ }^{2}$, \\ Elijah M. Siringi ${ }^{2}$
}

\author{
${ }^{1}$ Department of Management Sciences, Maseno University, P.O.Box Private Bag, Maseno, Kenya \\ ${ }^{2}$ Department of Marketing and Management, Maseno University, P.O.Box 333, Maseno, Kenya \\ *Corresponding Author: fredrick.aila@gmail.com
}

Copyright $(2013$ Horizon Research Publishing All rights reserved.

\begin{abstract}
This paper examined the effect of Information Systems on revenue collection of Local Authorities in Homa Bay, Kenya. Study objectives included establishing the relationship between internal control systems, Information Systems and revenue collection in Kenyan Local Authorities; determining the levels of quality service offered to the clients by Local Authorities and investigating whether Information Systems relate to effectiveness and efficiency of Revenue Collection. A structured cross-section survey was used to collect data from 2,007 individuals, of which 165 were Local Authorities staff and 1,842 were traders in Homa Bay Municipality. The study found that: there is a relationship between Information Systems and both efficiency and effectiveness in revenue collection, there is a strong positive relationship between Internal Control Systems and revenue collection as reported by $97 \%$ of the respondents, and that resistance to change by the council staff was derailing the full implementation of Information Systems. The study is useful in reviewing the institutions' Act and statutes to cater fully for the integration of IS in the management activities of Homa Bay Municipal Council, to managers at all levels, public sector, policy makers and scholars.
\end{abstract}

Keywords Information Systems, IS, Revenue Collection, Local Authorities, Homa Bay Municipality

\section{Introduction}

Information System (IS) is a mechanism that helps people collect, store, organize, and use information. According to Duff et al (1980), Information System is a collection of people, procedures, a base of data and (sometimes) hardware and software that collects, processes, stores and communicates data for transaction processing at operational level and information to support Managerial decision making. The basic purpose of any information system is to help its users get a certain type of value from the information in the system, regardless of the type of information that is stored or the type of value desired (Norton, 2006).

Since the Local Authorities (cities and Local Governments) are very important to the citizenry. They are the engines of growth and centers of development. They provide cultural; educational; management, research, commerce and political services. They also do offer employment, best health facilities and boost the country's economy (UN-HABITAT, 2004). For instance, the City Council of Nairobi, the largest Local Authority in Kenya, produces more than half of the country's Gross Domestic Product. This means that Local Governments are important institutions in a country's development. Kenya has a total of 175 Local Authorities categorized either as City council, Municipal councils, Town councils or County councils all of which are coordinated by the Central Government through the Ministry of Local Government the act as the main overseer on how these councils carry out their activities.

\section{Literature Review}

According to the of goal Information Systems, was not only to provide citizens, economic organizations, companies and institutions with a range of excellent and effective services, but they also created a new form of citizenship based on the participation of all individuals in the provision of services and the decision-making process which was aided by the intensive use of new Information and Communication Technologies. Further Web service portals could constitute a useful means of offering the services needed by all users then and in the future. At the same time, they embodied a new opportunity for the deployment of ICT after the disappointing results of the new economy and the unfulfilled promise of a revolution in business and economic activities.

ICT programs and e-governance policy initiatives had also gained international validity for the donor community as a catalyst of reforms in support of global development goals, including health, education, economic opportunities, poverty reduction and the environment (UNDP, 2003).

Various policy blueprints produced over the years argued 
that ICT was essential to increase transparency and accountability of government agencies, reduce transaction costs in service delivery and enhance participation of citizens, businesses and civil society in the workings of governments. Better accountability and improved transparency were the identified characteristics of good governance, and the latter became the condition sine qua non for the rich states and international agencies to supply aid to developing states (UN, 2002, 2003; UNDP, 2003).

Innovations and reforms in the governmental and bureaucratic apparatus through the introduction of ICT and e-government were therefore seen as important prerequisite for aid and global development policy initiatives (Ciborra et al, 2005).

Doll et al (1983), argued that IS department experiences increased demands and responsibilities and that the IS group in such constantly changing environment needed to keep up with a number of expectations. They further stated that as a consequence, improvement of services, not only resources, was vitally important. Enhancing the efficiency and effectiveness of the systems delivery, integration, maintenance, etc., along with better organization and control of the other IS processes were some of the possible ways that the IS organization could follow to ameliorate performance.

ICT could also be seen as recognition that policy and resource allocation processes needed to be opened beyond the closed circles of elites at the state level. But it was also possible to notice how new electronic capacities introduced in government have escalated to widen the scope and purpose of e-government. The aims were to devolve meaningful authority to local bodies, improve the capability of governments' agencies to transfer and exchange information, making them more accessible to citizens and to improve service provision, channelling citizens' and civil society's voices and increasing the accountability of their representatives to enable the move toward ICT enabled connected governance (UNDESA, 2008).

In March 2004, the Government of Kenya launched an ambitious three year (2003-2007) E-government Strategy (GoK, 2004). The strategy was designed to achieve a set of goals and objectives, namely, to efficiently deliver government information and services to the citizens; to promote productivity among public servants; to encourage participation of citizens in government; and to empower all Kenyans in line with development priorities outlined in the 2003 - 2007 Economic Recovery Strategy for Wealth and Employment Creation (GoK, 2004).

The Kenyan local governance system was composed of four tiers of Local Authorities, namely: Cities, Municipalities, Towns and County Councils. These councils were corporate entities that were established under the Local Government Act Chapter 265. In addition to the Act, the LAs drew their legal powers from the Constitution of Kenya, other Acts of Parliament, Ministerial Orders and By-Laws. There were 175 LAs in Kenya as at the time of the study which included City Councils, Municipal Councils, Town
Councils and County Councils with Ministry of Local Government as the overall overseer of their operations (Mitullah et al, 2005). Most of these LAs faced a number of challenges in realizing their mandate. The challenges included: delivery of infrastructure and services, financial management, institutional and legal framework, human resource capacity and managing rapid growth. These challenges had resulted in poor service provision and management and many analysts had criticized the LAs, and questioned their role in local development. This inefficiency had justified a re-examination of their role and the launching of the Local Government Reform Programme, which also included the decentralization of service provision and management, which was still in the initial stages (Waema, 2005).

In 1996, a decentralization initiative under the Local Government Reform Programme was launched focusing on strengthening LAs. The programme had three components: rationalizing central-local financial relations, improving LA financial management, including revenue mobilization, and strengthening citizen participation in planning and ownership of programmes. The reform programme had recognized the importance of LAs in enhancing economic governance, improving public service delivery, and increasing economic efficiency, accountability and transparency (GoK, 1999). The reforms had also included putting in place Fuel Levy Fund, Contribution in Lieu of Rates, user charges rationalization, single business permits and most greatly Integrated Financial Management System (IFMS). These programs aimed at restructuring the local public sector and more importantly, strengthening local level accountability mechanisms. The Kenya Local Government Reform Programme (KLGRP) was conceptualized by the government of Kenya in the early 1990s and became operational in 1996. KLGRP focused on deepening the legal, financial management and institutional reforms in Local Government sector. KLGRP began with financial reforms aimed at enhancing inter-governmental fiscal transfers, improving financial management, debt resolution, streamlining budgeting system and service provision capacity building for LAs. A key instrument in this process was the enactment of the Local Authority Transfer Fund (LATF) in 1998. The act provided 5 percent of national income tax to LAs in line with population, resource base and financial performance (GoK, 1999).

According to Stephen et al (2000), Control was the process of monitoring activities to ensure they were being accomplished as planned and correcting any significant deviations. This definition gave a brief but all inclusive definition. It indicated that control aimed at monitoring the activities to ensure that they are completed in ways that led to the attainment of the organization's goals. They further argued that effectiveness of the control system depends on how well it facilitates the organizational goal achievement.

Certified Public Accounts Research (1990) defined 
internal control as "the plan of organizational and the coordinated methods and measures adopted within a business to safeguard its assets, check the accuracy and reliability of its accounting data, promote operational efficiency and encourage adherence to prescribed management policies." Donald et al (1994), viewed internal control as a structure that comprises three elements, which are: the control element which entails management philosophy, organizational structures, the functions of the board of directors, management control, and personnel management methods; the control procedures which consist of policies and procedures that the management has established to provide reasonable assurance that specific objectives will be achieved; and the accounting system which refer to the methods and records established to identify, assemble, classify record and report an entity's transactions and maintain accountability for related assets and liabilities. This gives a view that internal control system extend beyond those matters which relate directly to the functions of accounting and financial departments; it thus incorporates both financial and non financial controls.

System controls in a computerized environment are classified as either general or application controls. General controls are designed to manage and monitor the system environment, thereby affecting all system related activities. They include control aspects such as segregation of duties, assignment of authority, management integrity and corporate governance, software acquisition and maintenance, physical and online security, access to data, and contingency planning- anything that involve entity-wide system concerns (Guldentops, 2001; COBIT, 2002). The primary objective of application controls is to ensure the accuracy and integrity of specific applications such as sales order processing or accounts payable. They include input, processing, and output controls within an application. Input controls relate to the data that is entered into the system; processing controls relate to transformation and output controls work to ensure that the processed data is distributed and utilized appropriately by authorized users for authorized purposes (Hall, 2002). General and application controls are interrelated and always taken together; they serve to ensure validity, accuracy, and completeness of financial of financial information produced by the current internal information system of an entity. System controls need to be understood as they relate to management's assertions, and regardless of their strength, their operational effectiveness needs to be evaluated (COSO, 1999; COBIT, 2002).

According to the study by UN-HABITAT (2010), on fundamental problem of municipal finance in Africa, which can be stated as the gap between financial resources and municipal expenditure needs coupled with inadequate financial systems. The study revealed that fiscal gap is widened as urban populations expand, increasing the demand for infrastructure and urban services. It was evident on the research findings that there exists lack of (municipal) income elasticity, the fact that the growth of municipal revenue does not match the increase in urban economic activity. The study further revealed that taxing powers of local authorities are not wide enough and the yield from existing sources is often far inadequate to meet their expenditures. The study also found out that many cities in Africa largely depend upon income derived from property taxation and other service charges, while other and more lucrative sources, such as income tax, sales tax and business tax are monopolized by central governments. Thus, many cities have to depend on central government allocations, which are generally inadequate and often erratic in terms of timing. The study also reveals that a common source of revenue in most countries is inter-governmental transfers.

\section{Methodology}

This study adopted a survey research design where primary data were collected from selected sample through questionnaires. This research design was preferred because it enabled the researcher to collect data from samples by administering well prepared questionnaires, which captured different aspects of Information Systems from opinions of the respondents. Stratified random sampling was employed to arrive at 116 council staff and 318 traders giving sample of 434 individuals from a population of 165 council staff and 1842 traders as at the time of the research. Both the primary and secondary data were used and analysis was done the frequency distribution (both simple and cumulative frequency distributions) technique

\section{Discussion}

The results from the study show that the council had adopted the use of ICT in the year 2012 when the study was conducted. This was evidenced from $96.3 \%$ of the responded who ascertain adoption of ICT by Homa Bay Municipal Council and only $3.5 \%$ disagreed. This meant that the council had enough ICT components necessary to support the operations within the council. This is so since both the traders and council staff had a common opinion on Council adoption of ICT. Further the council had adopted Information System in Revenue Collection. From the results of the study, $9.9 \%$ of the respondents strongly agreed, $47.5 \%$ somewhat agree and $38.7 \%$ agreed giving a total of $96.1 \%$ of the respondent generally agreeing that the council apply Information Systems in Revenue collection. This therefore leaves only $4 \%$ of the respondents from the sample population disagreeing.

Information systems had also taken revenue collection of Homa Bay Municipal Council to the next level, by boosting their revenue collection. However, more still needed to be done in terms of designing an appropriate method, for collection of revenue from those traders that remit their taxes on daily basis, or attract them using other means such as categorizing payment modes into; yearly or probably monthly payment mode which can be easily computerized as the permit system is. The number of traders that remit their 
taxes on daily basis is quite big accounting for $72.6 \%$ of all the traders who participated in this study. The study also showed that Information Systems that the council had installed maximizes revenue collection, especially the permit system where records are easily computerized. From the entire sample population, $10.1 \%$ strongly agreed with the point that IS maximizes revenue collection, $48.6 \%$ somewhat agreed while $36.6 \%$ agreed, giving a total of $95.3 \%$ of the individuals that attributed maximization of revenue collection of Homa Bay Municipal Council to the use of Information Systems. This further shows how efficiency and effectiveness of revenue collection has a strong positive relationship with the use of Information Systems as shown below.

\section{Maximization of Revenue Collection by IS}

Strongly Agree
Somewhat Agree
Agree
Disagree
Strongly Disagree
Total

$\begin{array}{ll}\text { Frequency } & \text { Percent } \\ 44 & 10.1 \\ 211 & 48.6 \\ 159 & 36.6 \\ 14 & 3.2 \\ 6 & 1.4 \\ \mathbf{4 3 4} & \mathbf{1 0 0 . 0}\end{array}$

Source: Survey data, 2012

The study showed the respondents opinions concerning financial controls with the influence of ICT. Over $85 \%$ of the respondents were of the view that adoption of ICT had indeed enhanced tighter financial control within Homa Bay Municipal Council. From the study, $80 \%$ of the respondent believed on the positive impact that Information system had on financial control. This strong positive impact led to even an improvement of management integrity, as the system streamlined services to suit both staff and clients who were the traders. Generally $97 \%$ of the respondents indicated that indeed, information systems had improved the integrity of the management of Homa Bay Municipal council, probably due to the enhanced financial control that the same information system is a factor to.

Contrary to the first two objectives, the study revealed that even though the council had adopted use of ICT in most of their operation such as revenue collection, the quality of services offered by Homa Bay Municipal Council still remained at very low levels. The traders were not satisfied with the kind of services that they receive from the council owing to the heavy taxes that they paid. $61.3 \%$ of the respondents on responding to whether the Information systems did improve the quality of services offered to clients by the Homa Bay Municipal Council, disagreed. The percentage showed the level of dissatisfaction that the traders had on the council service provision. This meant that only $38.5 \%$ of the respondents were satisfied with the kind of services offered. It is also very clear that the percentage of the traders satisfied could be much lower than $38.5 \%$ since this percentage include both traders and council staff that participated in the study. The lower levels of the quality of services offered by the council could be attributed to the low commitment that the council had on using Revenue Information System. $76.3 \%$ of the respondents questioned the commitment of the council in employing the use of ICT. As the study revealed, all the computer hardware and software that were necessary to support the council operations in serving the clients were available. What was found to be lacking was the commitment in using ICT. The study further revealed that the council did not base their decision making on the records provided by the information system. This therefore meant that most records provided by the information systems were formality since the government is advocating for the use of ICT in the public service provision. Out of the 434 individuals who were sampled for the study, $86.9 \%$ were of the view that Homa Bay Municipal Council did not base their decisions on data generated by either ICT or Information Systems that the council had already installed. Finally, the study also revealed that the complaints made by the clients did not decline even after the council had begun to employ use of ICT. This was an indication of status quo by Homa Bay Municipal Council on their activities.

This compares so well with the challenges posed by Mitullah et al (2005) on the State of ICTs and Local Governance in Kenya that revealed Local Authorities play a central role in local economic development in Kenya, but face a number of challenges which include, collection, storage and dissemination of information. Most of these authorities, like others in Africa, rely on manual file based information storage with hardly any dissemination taking place. They further revealed that Local Authorities faces a number bottle necks while discharging their duties due to the fact that ICT facilities are still limited in Local Government Institutions and also technical skills on how to apply ICT is still very low. The latter seems to compare will with the situation of Homa Bay Municipal Council.

\section{Conclusions}

Based on the research findings, the study concluded that investment in ICT is very important to Local Authorities. This is because computerized Information Systems has a positive effect on revenue collection. Computerization of council activities such as revenue collection enhances efficiency as a result of timely revenue collection, enhancing management integrity, provision of clear records among other factors. Information systems also improve the operations that are facilitated by the Internal Control Systems which in turn enhances efficiency and effectiveness of the council.

The study confirmed that Internal Control Systems relate to revenue collection. Tighter ICS were found to have positive relationship with revenue collection. It was further found that IS enhanced tighter financial control of Homa Bay Municipal Council. This was further found to have increased 
management integrity according to how both the council staff and the public perceived the management of Homa Bay Municipal Council.

The study also found out that even though the council had adopted use of Information systems on revenue collection exercises, and other operations, quality of services offered by the council are still very low. Study further revealed that the council was not committed to fully utilizing Information Systems and ICT in general in carrying out their operations. Specifically it was found that the council did not base their decision making on ICT based records even though such records were available. This was an indication that ICT adoption was a formality since the central government was advocating for all Government Ministries to adopt ICT and all local authorities which are extended part of Government through the Ministry of Local Government. As a result complaints made by the public and clients were on the rise even after the adoption of Information System and ICT in general.

The study was recommended to be useful in reviewing the institutions' Act and statutes to cater fully for the integration of IS in the management activities of Homa Bay Municipal Council, to managers at all levels, public sector, policy makers and scholars. Finally, the researcher recommended the following areas for further study consideration; the staff's attitude towards the adoption of ICT in Local Authorities in Kenya and establish if they fully embrace the use of ICT, the degree of computerization of revenue collection exercises and its cost-effectiveness, and the impact of Internal Control Systems (ICS) on revenue collection of Local Authorities.

\section{REFERENCES}

[1] Ciborra, C., \& Navarra, D.D. (2005), Good Governance, Development Theory and Aid Policy: Risks and Challenges of E-Government in Jordan, Information Technology for International Development, 11(2), 141-159.

[2] COBIT (2002). Control Objectives for information and Related Technology (COBIT) (3rd Edition). Information Systems Audit and Control Foundation (ISACF)

[3] Donald, H. T. et al (1994). Auditing-Integrated Concepts and Procedures, 6th Edition, John Wisely and Sons, inc. NY

[4] Duff, W.M. and Asad, M.C. (1980), Information Management: An Executive Approach, Oxford University Press, London, p. 243.

[5] Government of Kenya, (GoK, 2004), E-Government Strategy: The Strategic Framework, Administrative Structure, Training Requirements and Standardization Framework, Cabinet Office, Office of the President, Nairobi: Government Printer.

[6] Guldentops, E. (2001), Harnessing IT for secure, profitable use, Information Systems Control Journal, Vol. 5, pp.45-47.

[7] Mitullah, W. V, et al. (2005), Management of resources by local authorities: The case of Local Authority Transfer Fund.
Nairobi, CLARIPRESS

[8] Norton, P; (2006). Introduction to Computers. McGraw-Hill Technology Education. China

[9] UN. (2002), E-government for development: Final Communique of the International Conference on E-Government for Development, Palermo.

[10] UN. (2003). First Annual Report of the Information and Communication Technologies Task Force, Economic and Social Council of the United Nations, Retrieved 14 March, 2012, from http://www.

ictdevlibrary.org/downloads/un_ict_task_force_first_ict_rep ort.pdf.

[11] UNDESA. (2008), United Nations e-government survey 2008, New York: Department of Economic and Social Affairs Division for Public Administration and Development Management.

[12] UNDP. (2003), Information and communication technologies for development in human development reports, New York: United Nations Development Programme.

[13] UN-HABITAT. (2004), Challanges of Municipal Finance in Africa, Nairobi: United Nations Human Settlements Programme

[14] Waema, T. M. (2005). In Etta, F. E. and Elder, L. (eds.) A brief History of the Development of ICT policy in Kenya. (At the Crossroads: ICT policy making in East Africa, pp. 25-43.) Nairobi, Kenya: East Africa Educational Publishers Ltd.

[15] Doll, W. and Ahmad, M. (1983), Management Users' expectations, Journal of Systems Management, Vol. 34, pp. $8-11$.

[16] Republic of Kenya (GoK), (1999). Report of the rationalization and staff rightsizing for effective operation of the Ministry of Local Government. Nairobi: Government Printer.

[17] Stephen, P. R. et al (2000). "Management" Prentice Hall, $5^{\text {th }}$ Edition, India.

[18] Hall, J. A. (2002). Information Systems Auditing and Assurance, South - Western College Publishing.

[19] COSO (1999), Research Prompted by the Committee of Sponsoring Organizations of the Treadway Commission, Fraudulent Financial Reporting, 1987-1997. An Analysis of U.S. Public Companies

[20] COBIT (2002). Control Objectives for information and Related Technology (COBIT) ( $^{\text {rd }}$ Edition). Information Systems Audit and Control Foundation (ISACF)

[21] UN-HABITAT. (2010), Challanges of Municipal Finance in Africa, Nairobi: United Nations Human Settlements Programme 